\title{
Frances Devlin-Glass
}

\section{Deakin University}

\section{'Bloomsdaying': James Joyce in performance and the more-common-than-you-would-think Reader}

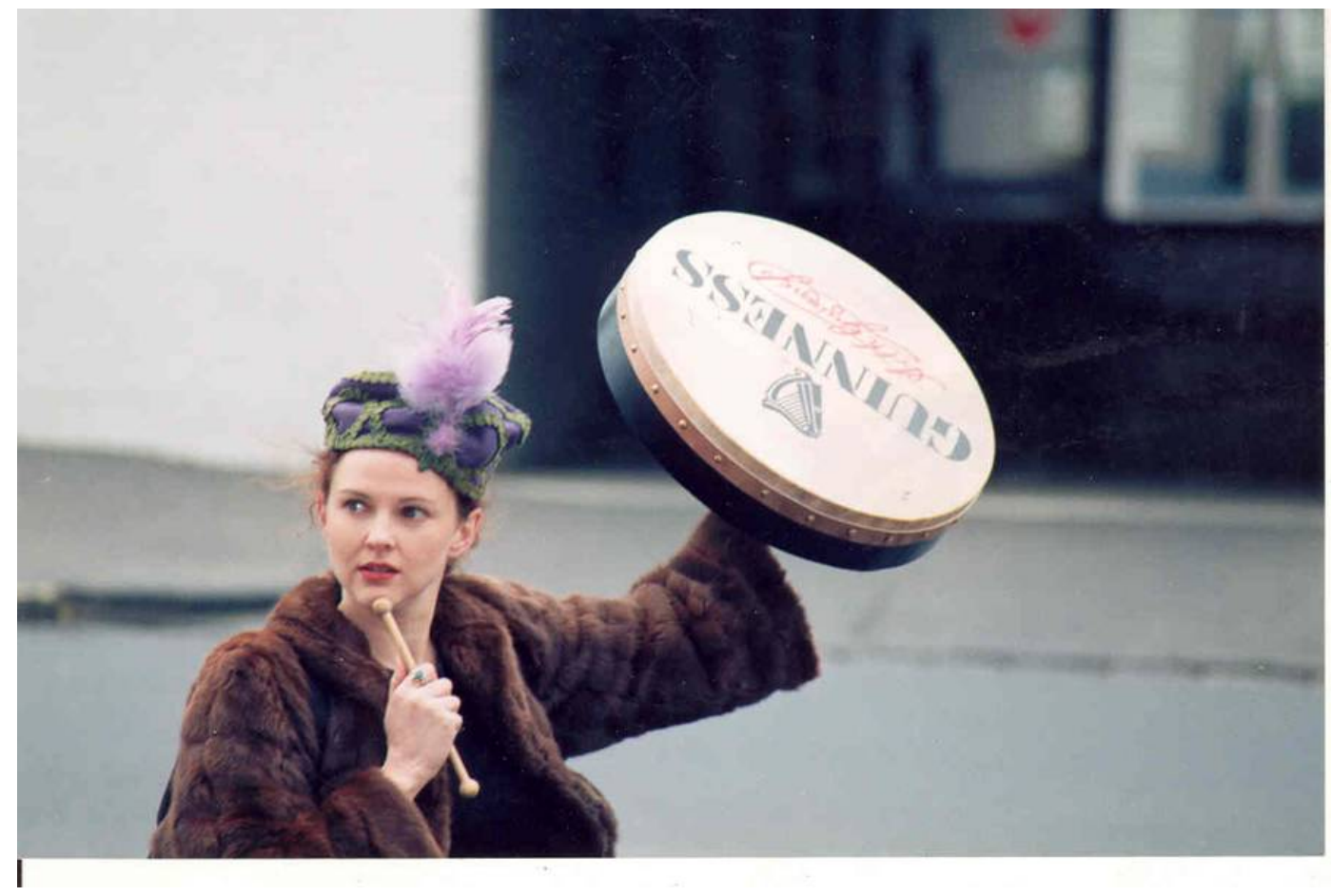

Roz Hames, writer and committee member, leads patrons through the lanes of North Melbourne in 2000.

To study the Bloomsday festival patrons in Melbourne is to reveal both the chasm which exists between the educational élites and real 'on-the-ground' readers, and to demonstrate some ways in which that is being bridged. Academe, and following them, some influential members of the press, routinely bemoan, often using discourses created by modernism, how their prime canonical construct, Joyce, has been put beyond the reach of 'common' readers. However, by studying the reading and attendance behaviours of the patrons of a small Joyce-focussed festival, a different and quite startling case can be made about new formations in book-consumption and how 'consumers' engage with the literary establishment. One could argue that, despite its prepostmodern élitism, literary academia has created a taste for Joyce, but in Melbourne the picture is more multi-stranded than that, less exclusively literary and more polyvocal. Reading and enjoying Joyce is not necessarily an encounter between academics and the unwashed. Why?

Because Joyce is arguably the most canonical writer of the twentieth century, appearing regularly on ' 100 best book' lists, it is easy to forget how recent a development Joyce's canonisation is. In Australia, teaching of Ulysses began in the 1940s in Mechanics Institutes, but it was institutionalised much later in universities (often in the late 1960s, 
but in Adelaide, the 1980s) (Devlin-Glass), so it is a text that in some ways is not well known, even in among literary academics. Its reputation for difficulty daunts many. Although by their very nature ephemeral, the legitimacy of 'best books' lists (eg., Random House, Joyce's publisher, generated one of the more controversial lists) is questionable (note 1), being often generated by publishers and vulnerable to literary fashions. Nonetheless, there is evidence that Ulysses has become a holy grail for some readers. Why? Is it the challenge? Does the difficulty raise the stakes? Many of Bloomsday in Melbourne's patrons talk of it as high-class consumer good (note 2), perhaps akin to an up-market car. Joyce as the BMW of Literature? Why do people want to be able to read Ulysses? Joyce hysteria is routinely generated each June in the serious press which seems to feel obliged in the week leading up to Bloomsday to do a piece, and to find a fresh angle. However, in reporting on Bloomsday there is a frustrating degree of ennui, of cynicism (even in Dublin [note 3]) and a tendency to want to caricature it as a Guinness-fest, an occasion akin to St. Patrick's day with its feast-day excesses (note 4). Is increased interest in the newspapers a sign that the novel is passing into a more general currency? Joyce doesn't yet have the status of Shakespeare, but is compulsoriness the next stage? Or does the current anti-canonical moment protect Joyce from becoming the text one pretends to read?

Although academics and writers (who often cite their debt to Joyce) may fuel the Joyce hysteria, they do not, however, share the press's relatively democratic take on him. Kingsley Amis, for example, is critical of Joyce's lack of user-friendliness, but is prepared to call Joyce a genius who makes Beckett look pedestrian, Lawrence diffident and Nabokov guileless (J. Brannon p.100). The senior Joyce scholar, Colin McCabe, goes further, claiming that Joyce is the only possible reader of Ulysses:

It is obvious from Joyce's disappointment at the reaction to Ulysses and Finnegans Wake that he entertained some notion of the common reader to whom his texts would be available. But this purely imaginary audience did not exist and the real audience to whom the texts are thus necessarily addressed is an isolated individual and the only possible individual: Joyce himself...

The only section of society that shares an imaginary identity with Joyce are the Joyce scholars and it is they who form his only audience (McCabe p.160).

His is a curious and contradictory claim; his footnotes, though, indicate he means it to be taken literally. Joyce's extraordinary single-mindedness and his persistent efforts to find a publisher for Ulysses, as is attested most forcibly in Joyce's letters to Pound (Read passim), give the lie to McCabe, indicating a writer who clearly intended to communicate, who took a great interest in responses to his fiction. He is also reported as commenting to his publisher that the concierge's son would one day be his reader (Ellmann p.504). More usually, what the academics remind the great unwashed of is Joyce's (jocular) threat to keep academics busy for 100 years.

Julie Brannon's Who Reads Ulysses performs useful historical work in demonstrating how Ulysses, to get past both the censors and Justice Woolsey, mobilised respected academic opinions and supporters, in the process disempowering the 'common reader'. Critical to the novel's being declared not pornographic was the distinction between the erudite and learned reader who could not be morally polluted by it and the common reader who, it was claimed, would not persist with it. Subsequently, she argues, the text was commandeered by the academics. Those with a stake in promoting its lack of interest to general readers she identifies as gurus who protect and promote their expertise in increasingly technicist ways, often theoretically based, about arcane matters of editorial methodology. Those general readers (note 5) I've studied have no interest at all in these debates. The chief advertising ambit of the now illegal first Dublin edition of Ulysses (Rose), republished in 2004 in the UK thanks to a legal technicality, was its claim to restore the text to 'readers' by inserting hyphens in Joyce's compounds and other similar distortions of Joyce's intentions (Jones). Behind many of the controversies over Joyce stands the spectre of the grandson, Stephen, who loses royalties (and potentially control) if a new estate-authorised edition is not produced. Hans Walter 
Gabler's three-volume Critical and Synoptic Edition of Ulysses (Joyce et al.) and its trade-edition counterpart from Random House (the so-called 'Corrected Text') with its cover blurb by Hugh Kenner ('the pot of gold at the end of a 20th century scholar's adventure') had seemed to be that text, until attacks on its editorial integrity and postmodern editorial practices sank it (Brannon). Rival editor, John Kidd, mounted the attack, but vested interests in the Joyce estate have succeeded in stalling publication since 1992. Brannon makes a convincing case that the common reader constructed in the rhetorical discourses of these 'Joyce Wars' is purely abstract. While conceding that the academics engage in an excluding rhetoric, and despite the title of her work, she is frank about not knowing who among those outside of academe read it (J.S. Brannon).

Far from believing that the only readers of Joyce are Joyce scholars, as an academic and an organiser of Bloomsday, I have watched audiences scramble over one another for tickets for 11 years, observed them becoming Joyce addicts (not unlike Kate Molloy, see footnote 2 above), and hear them report on their successful overcoming of the obstacle-course that is reading Joyce, often between one Bloomsday and the next. The festival in Melbourne sells out every year with a minute advertising budget.

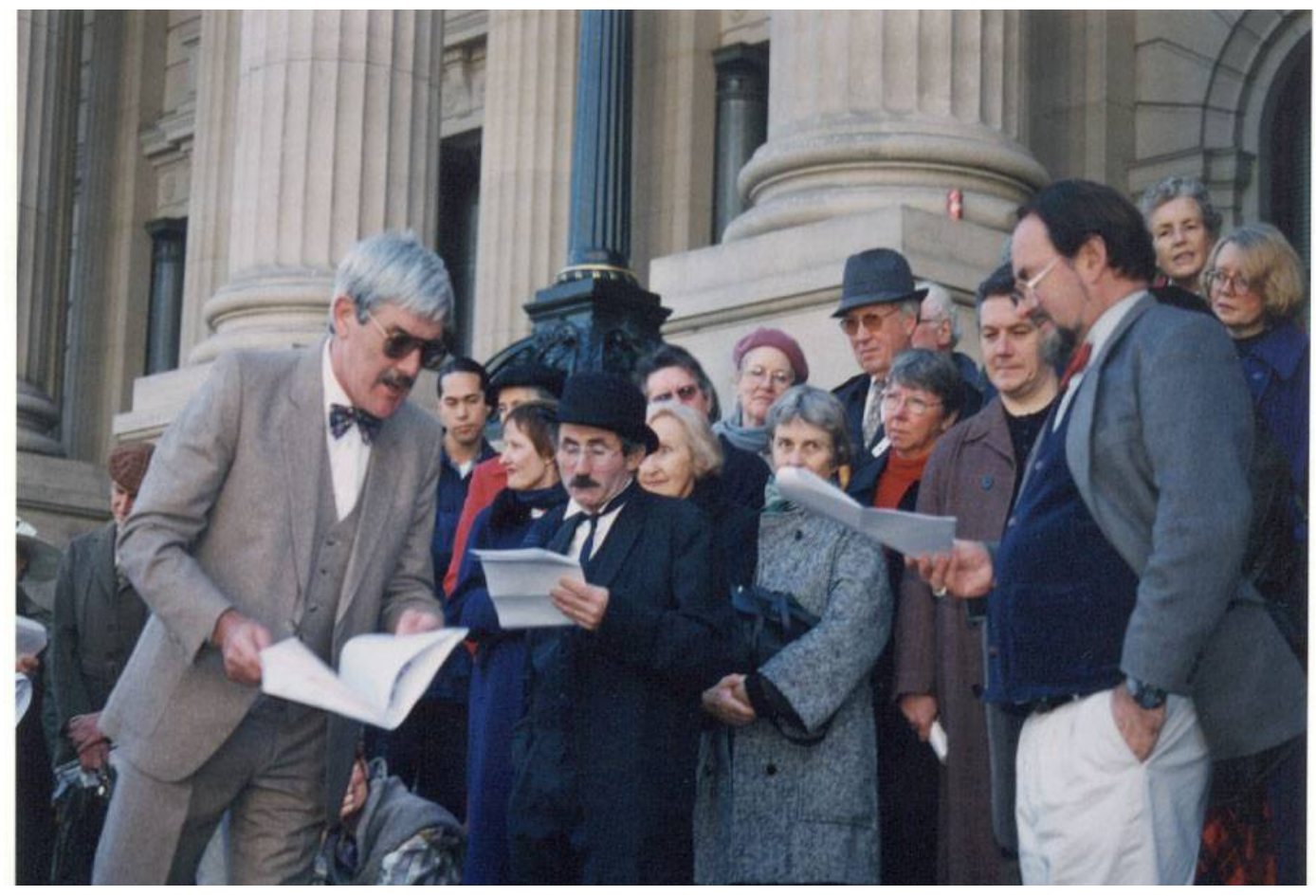

Figure 1: Patrons (and performers), script based on Aeolus episode, performing on the steps of Parliament House, Ulysses and Myth, 1999.

What, then, is the profile of Bloomsday in Melbourne patrons? They are mostly older than 40; indeed the highest proportion are over 60, a statistic which is worrying for the organisers. However, they are patrons who are time-rich, or flexible in their work arrangements and able to devote a day to the festival. They are overwhelmingly tertiary educated, $86 \%$ with a first degree and $41 \%$ of these with an additional higher degree (Figure 2). 
Figre 2: Melboume Eloomsday Patrons by Level of Education

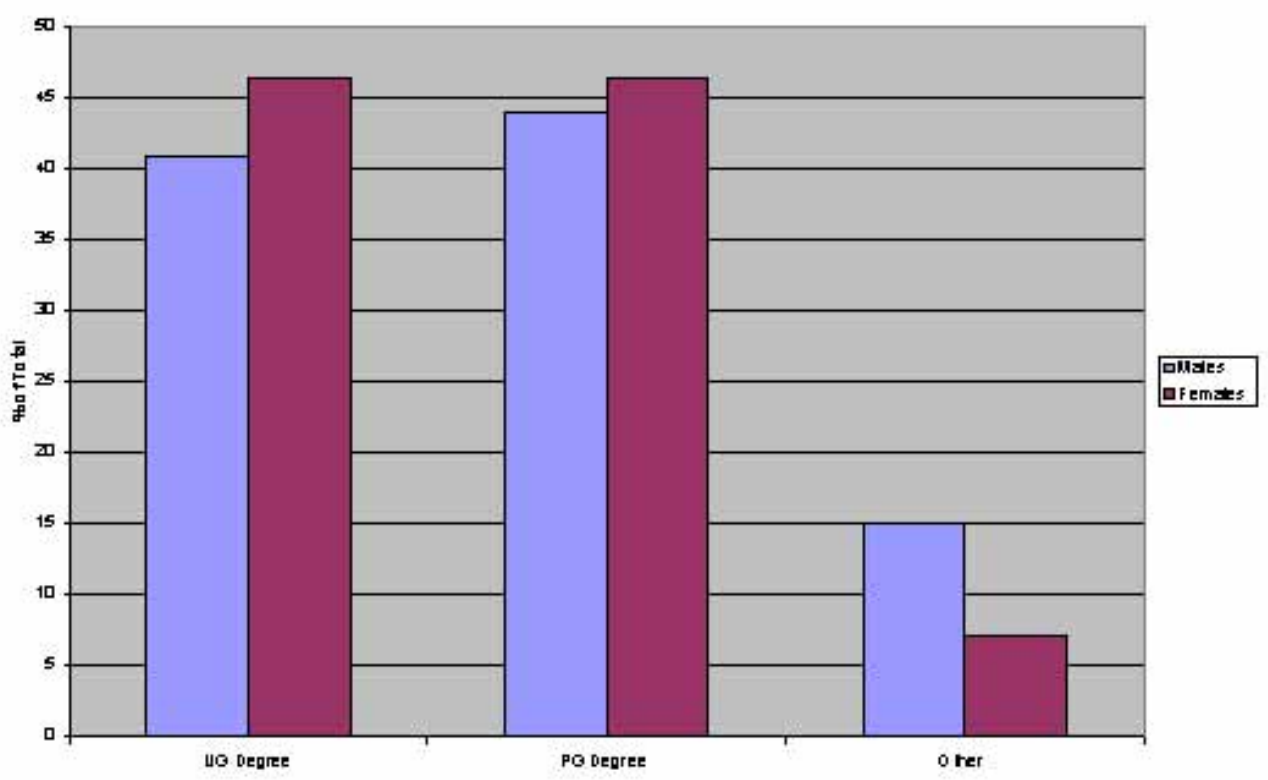

How are they employed? Respondents were engaged in a great diversity of occupations: they included doctors, nurses and medical professionals, 4 psychologists, a farmer, a winemaker, engineers, IT professionals, lawyers, many writers from across the spectrum (literary and journalistic), bureaucrats and secretaries, 7 teachers (all but one retired), 7 actors, and academics from non-literary disciplines like Law, Education, Physics and Philosophy. A very small proportion were literary-trained in the usual sense. They are almost equally spread between Australians (or Australians with forebears other than Irish - many in fact are Jewish) on the one hand, and those who identify as Irish-Australian and those born in Ireland on the other. The reasons for reading Joyce and attending Bloomsday are somewhat different in the Irish and IrishAustralian populations, reflecting the different identity formation needs of the sons and daughters of pre-1960s migrations and the New Irish migrants.

How much Joyce have they read, and why do they read Joyce and attend Bloomsday? The answers to these questions have been canvassed more fully in papers on their literary dispositions (Devlin-Glass, forthcoming in the James Joyce Quarterly) and their Irish investments as readers of Joyce (forthcoming). However, a brief overview is appropriate here, and the answers are indeed surprising. The organisers had made the same assumptions as Brannon and the academics, and were astonished by how misplaced their expectations were. They assumed, erroneously, that they were on a mission to take Joyce to the Joyce-illiterate. The patrons (a self-selecting group) have been reading Joyce for a long time: $59 \%$ of the women (and $44 \%$ of the men) for more than 20 years (Figure 4), and some for as long as 40 or 50 years. 
Figure 3 : Proportion reading Joyce's Major Works

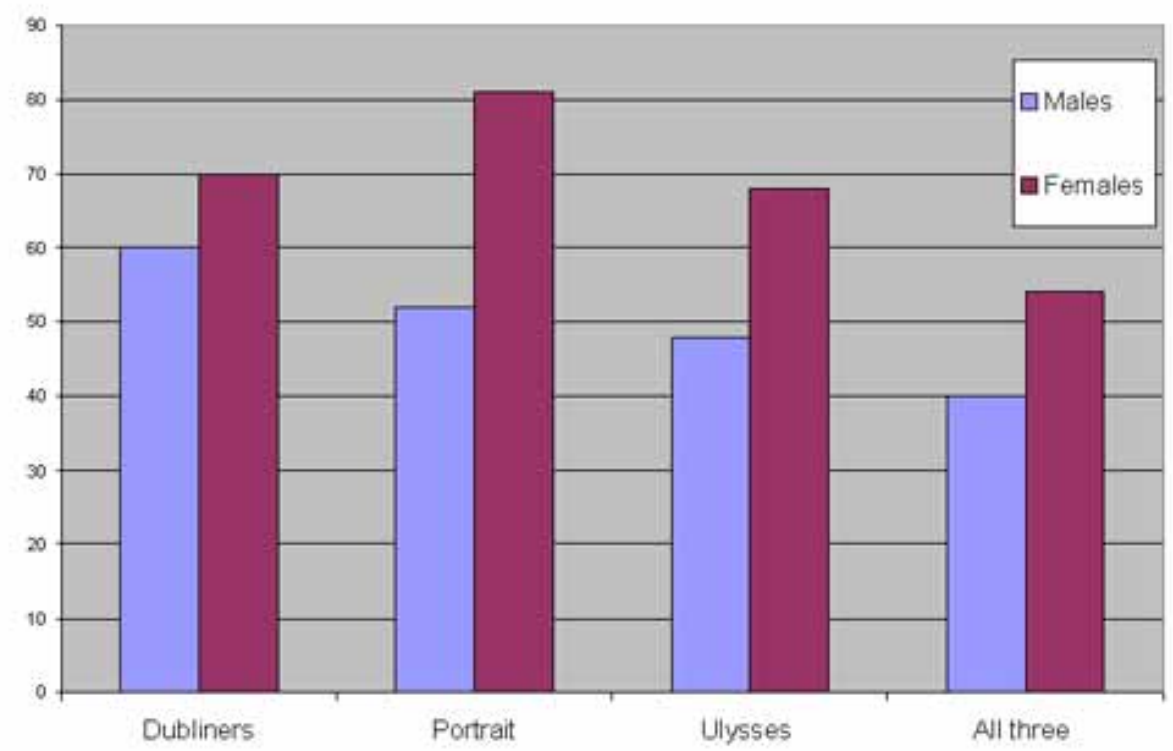

Many report a regime of continual re-reading and of incremental understandings as they re-read, and see the enterprise as one for the long haul. They do not attend Bloomsday in order to understand Joyce; rather, having read Joyce is a key motivator for attending Bloomsday. One attendee commented:

Bloomsday is fun, but I feel you really need some grasp of the text to really enjoy it.

And, the more they have read of Ulysses, the less likely they are to see Bloomsday as a substitute for reading Joyce. Those who express radical insecurity as readers of the novels are rare (I can identify only two respondents whose educational background and sense of lack make them dependent readers), and they especially appreciate the festival. Both are highly motivated. One, an Irishman, has spent between 1 and 3 years reading and the other has invested more than 33 years in attempting to read the novel. Like this insecure reader, most respondents identify themselves as readers of Joyce for the long haul, and comment on how incremental advances in understanding have been the norm for them. A few are able to chart seismic shifts in the tectonic plates of their understanding. One literary-trained respondent noted that his reading had shifted in two main phases (as a senior undergraduate and then returning to the novels 10-15 years later) in response to understandings about Joyce's style as a structural device:

- 1. circa mid 1970s age 20: in order to understand Ulysses one had to accept that the episodes were written in different literary styles and this was part of the meaning.

- 2. age 35: the blinding recognition of $U$ 's subversiveness, that Joyce was dramatizing and exposing the secrets of Irish society through discerning humour.

- 3. age 30: that Finnegans Wake is not read A-Z but, like the Bible, is a return to wherever you are up to. Now I begin to think FW is a set of books, not one book again like the Bible.

Another respondent, a woman, tracked the changes in her reading more in social and identity terms:

The greatest advance happened when/as my attitudes to Catholicism became more complex and critical. Another when I visited Ireland. The rise of Feminist writing in 70s onwards challenged some of the assumptions about sexual behaviour and reading which I had possessed - interesting re Molly Bloom and male characters' attitudes. 
The questionnaired are much more deeply read in Joyce than the organizers surmised. Slightly more than half claim to have read all three of Dubliners, A Portrait of the Artist as a Young Man, and Ulysses. An astonishing (but nonetheless small) proportion of the sample (14\%) claim to have read the Wake, and while $35 \%$ of the sample had read the Wake in part, only $7 \%$ have definitely decided it is not to be attempted or revisited. It is Finnegans Wake, and not Ulysses, which is the frontier for these festival attenders. Their main motives for they advance for reading Joyce are literary ones (and although not literary trained, they are remarkably literary in how they identify their reading difficulties and pleasures), though identity-formation is clearly an important motive for Irish-born and some, but not all, Irish-Australian readers, and they can be summarized in the following diagram (discussed more fully in Devlin-Glass, forthcoming):

\section{Figure 4: Most Common Reasons for Reading Joyce}

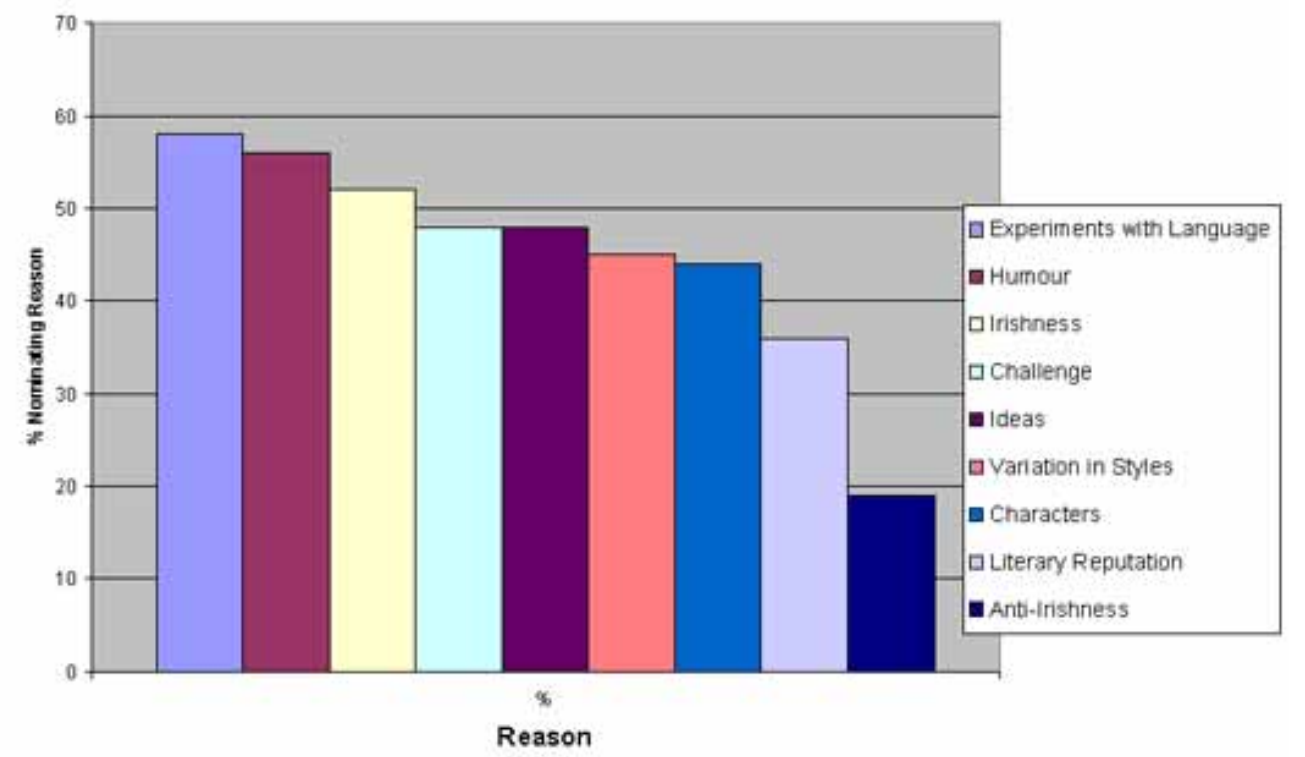

In the questionnaired group, which includes a high proportion of serial attendees, 100\% endorse, sometimes enthusiastically and sometimes with reservations, the way in which Bloomsday extends and enriches their engagement with Joyce. Asked about key moments of comprehension in their Joyce-reading history, they identify Bloomsday as accelerating their understanding, many noting how much more comprehensible Joyce is to the ear than to the eye, reading on the page:

...[Bloomsday] allows me to hear Joyce, it makes him more accessible. I am less intimidated by him.

Yes, listening to tapes; hearing speakers talk about their understanding; Bloomsday in Melbourne has been instrumental in improving my understanding and appreciation of Joyce;

When I first heard Joyce read out aloud I felt that I understood so much more. This was in a pub at a reading on Bloomsday in Melbourne;

Bloomsday inspires me to read certain passages. The 'difficult' parts are just a 'slog';

...it is personal, but Joyce has encouraged me to enjoy the sound of the English language as spoken by the Irish;

a valuable alternative; solitary reading too difficult and too timeconsuming;

[Bloomsday] stimulates the appetite for further reading; 
Perhaps [Bloomsday] is the lazy person's Joyce, but it is so well done and would stimulate a reader with time;

and

It is good to hear Joyce being read and see sections being performed.

Then one can return to the text.

It would be possible to make too much of the literary reasons offered for festival attendance and these are undoubtedly significant, as is the focus on Joyce whom these readers tend to accept unproblematically as a great writer. However, quite clearly there are a range of sub-cultural and social issues that constitute a glue for the festival and which begin to explain serial attendance. Asked why they think others go to Bloomsday, participants talk of the patrons as a subculture of 'eccentrics', 'buffs enjoying an in-joke', a 'rarified' or 'pretentious' gathering and the event as a 'cultural escapade', 'cult' or 'rite' and of wanting 'to see what other Joyce readers look like,' but many more talk of it as a social event entailing 'belonging to a literary family.' When the same people talk of their own reasons for attending, they are far less likely to play up the discourses of élitism, carnival and eccentric subcultures, and more likely to employ a simpler and more conventional language of friendship, enjoyment, and learning about Joyce. The questionnaire responses and feedback both about festival offerings and to a newsletter instituted in 2003 also suggest that this subculture has a strong sense of internal identity focussed on Joyce and its own existence, and that the networking skills of two secretaries and word-of-mouth are significant features of its ongoing viability.

A brief history of Bloomsday in Melbourne gives some idea of what it is this population 'consumes' during their annual Bloomsday 'fix'. The taste for Joyce predates the peripatetic Joyce festival. Continuous readings at poet, Kris Hemensley's Collected Works bookshop (complete with Guinness, soda-bread and paté) continue to this day, and theatricalised readings at Molly Bloom's pub preceded the Yeats Society initiative of 1994, which was the genesis of Bloomsday in Melbourne Inc. Joyceans broke with the Yeats society in 1995, after its second year (note 6). Those getting it up include one academic, and (in any one year) between 7-10 writers/readers/enthusiasts. The committee employs up to 50 professional actors, musicians, stage and lighting crew and paper givers in a single year, but more usually around 20-30 people. The organization is non-proft and money raised goes to professional actors/musos/dancers and pays for production costs (which are minimal) and venue hire. Many performers, including patrons who work as once-a-year readers, volunteer their services.

The festival has several innovative and distinctive features: it is peripatetic using Melbourne as a giant set; and it is thematised and refreshed annually. From the start, Bloomsday in Melbourne sought venues that were either like Dublin, or were thematically apt. Unlike Dublin, Melbourne does not have the locations, so they have to be recreated. This imperative has for the organisers become an opportunity to know the city, get to meet the residents and the local historians, whose research often gets incorporated into theatricalisations or provides invaluable resource material which materially influences the shape an event takes. To use Melbourne itself, and its different precincts, as the set serves to indigenise the novel; it is way of laying claim to ownership of it. Many examples could be offered:

- The Scandal of Ulysses (1997), with its account of the pornography trial and issues of censorship took players into the legal precinct of the city;

- an analysis of Joyce's attitudes to himself as a worker and to work and workers more generally, involved putting him through an enterprise bargaining case (where he was required to defend his views as a worker and ddepictor of workers) at Trades Hall (2002), a boom-time icon of industrial action in Melbourne; a mural in socialist realist style became a palimpsest on which to project Joyce's working class characters and from which they could give advice on how to conduct his case and bemoan his treatment of them;

- Writerly Joyce (2003) entailed the use of the newly refurbished domed reading room of the State Library of Victoria which doubled not only as a monument to literary learning with its engraved names of writers etched in gold around the 
dome, but also as Mina Purefoy's pregnant belly into which sperm balloons might be loosed for a dramatization of the Oxen of the Sun episode;

- a hospital ward at St. Vincent's Hospital became the stage for a commissioned ballet of the Swift parody from Oxen of the Sun (1999), involving the castration of a Papal Bull;

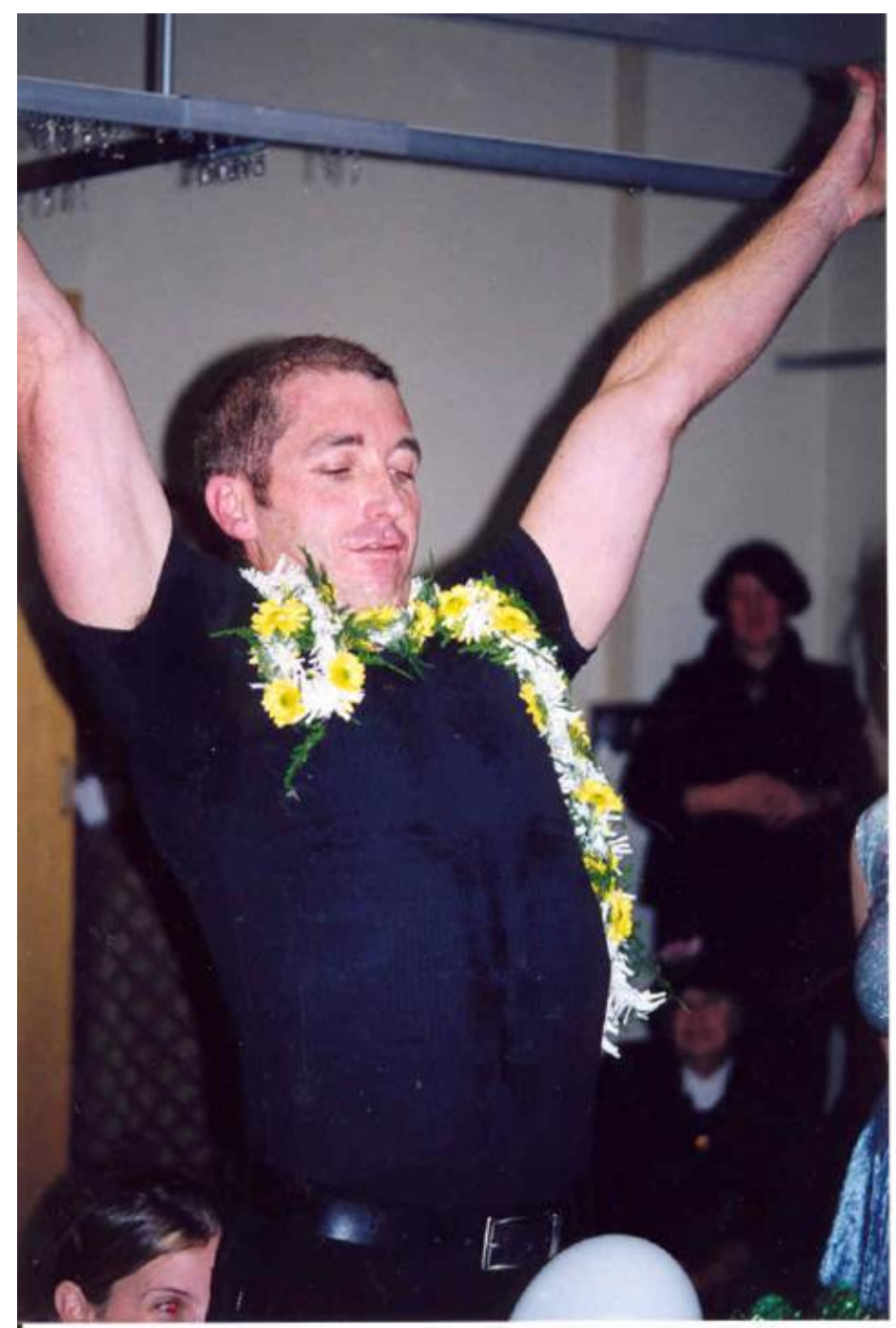

Philip Ayres, Irish Dancing Champion, as the Papal Bull, garlanded by the pious women of Ireland, and vulnerable to castration by ecclesiastical authority.

- while Melbourne's oldest morgue at Williamstown (1998) became a suitably under-worldly site for a black mass from Circe;

- the Legion of Mary headquarters in North Melbourne (2000) was the site for a dramatization of Gerty's Blessed Virgin Mary-identification;

- the entrance to Parliament Station (1999) became a gateway to Hades and simultaneously Glasnevin Cemetery for Bloom's meditations on mortality and meetings with his ghostly father and son; 


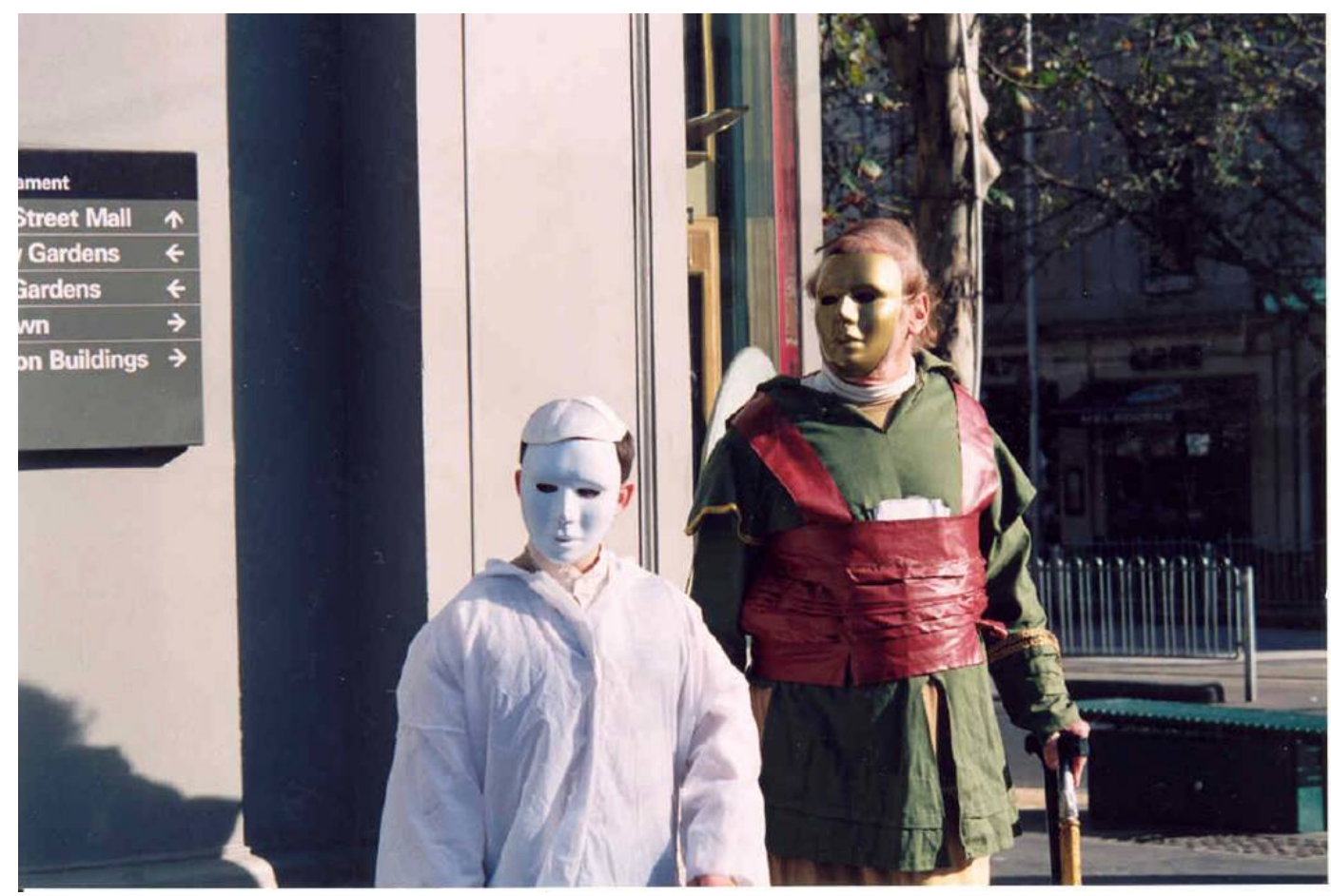

The ghost of Bloom's son Rudi and Achilles at Parliament Station, for Mythic Joyce.

- a bluestone erection and pier at South Melbourne doubled as the Martello Tower and the beach as Sandymount Strand for readings from the Telemachiad (1996).

The original idea may have been to recreate Dublin in a city that in many respects resembles it, especially in its early twentieth-century architecture and geographical location astride a bay, but by 2000 another set of imperatives became operative. 


\section{BLOOMSDAY \\ IN \\ MELBOURNE}

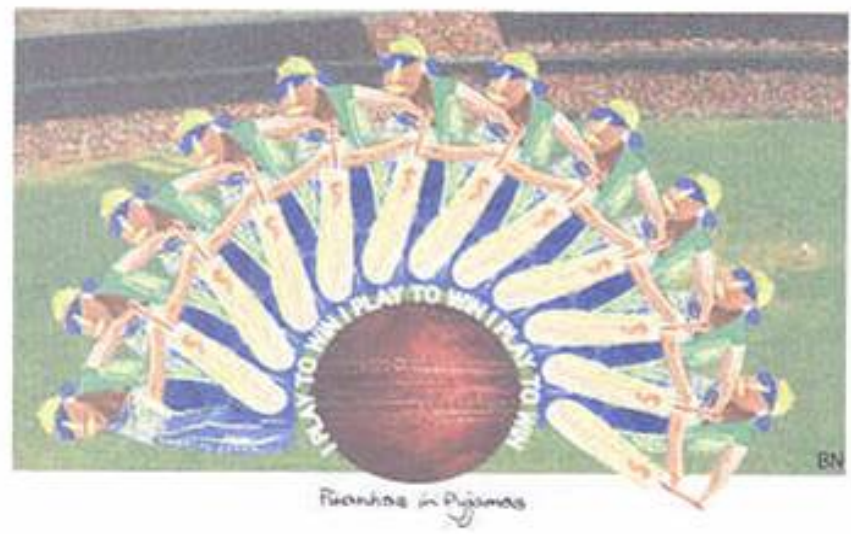

ANTIPODEAN JOYCE

\section{NORTH MELBOURNE \\ FRIDAY 16 JUNE 2000}

Program cover for Antipodean Joyce, which featured a First Eleven of Readers. Cover design, drawing on a contemporary image of Shane Warne, by Mary Newsome.

The program, Antipodean Joyce 2000

lam Murray Darling Embraces Anna Livia and Everybody is Somebody Else.

Queen Victoria Market Food Hall

11.45 Collideorscape: Walking tour of North Melbourne (or is it Ulysses?)

Lanes, pubs, shed A at the Queen Victoria Market, balconies and verandahs, the Legion

of Mary headquarters, Spinifex Press, an optometrist's, St

Joseph's College, St Mary's,

but not the Meat Market.

1.30 Variety Meats at Café Hotel (Joyce on food)

480 Victoria Street, North Melbourne

\subsection{Eine Kleine Wordmusik on Elmstrasse}

An oratorio, derived from Finnegans Wake, composed by Rod Baker

Uniting Church Hall on Elm Street

1. Sirenade

2. The Auditor-General is Dead! Long Live the Auditor-

General! 


\subsection{Live-it or Cricket: the Antipodean 'First Eleven' talk} Joyce at North Melbourne Town Hall

7.30 The Seven Ages of Joyce (A musical biography of Joyce) Sokol, the Czechoslavakian Club, 497 Queensberry St. North Melbourne

Antipodean Joyce was more research-driven in its focus on how North Melbourne slums compared with Dublin ones in 1904, and took many laneways into that comparative history. This particular year's approach instigated a double-vision which has since then become a normative way of operating for Bloomsday in Melbourne. In 2002 at Trades Hall, oral histories of slum life in Dublin were used to show how unconsciously middle-class Joyce's Dublin in fact tended to be. Since then, Melbourne and its formal and vernacular histories have been required to enter into a dialogue with Joyce's texts. So, the bullet-holes made by Squizzy Taylor at the Trades Hall were usefully deployed as part of a reading on Joyce's take on the excesses of militarist nationalism. The location of Bloomsday events shapes how Joyce is read in important ways, and though the priority is Joyce's fiction, the angle is invariably that of Australians reading Joyce aslant and interrogatively.

1994-2004

\section{Bloomsday in Melbourne Offerings}

Year

Theme

Venue

$2004 \quad *$ Her Song be Sung (Joyce and women) * Dublin, The Sugar Club

Club, Melbourne

* Back to Basics at the Celtic Club

* Celtic

2003

* Writerly Joyce

* Celtic

Club \& State

Library of

Victoria

College, Japan

* Modern Love Exposed * Kobe

2002 Joyce and Work Trades Hall,

Carlton

2001 Seawrack and Seaspawn (Cycles of Port

Melbourne

Decay and Regeneration)

$2000 \quad$ Antipodean Joyce

Victoria

Market and Port

Melbourne

1999 Mythic Joyce

Eastern

Hill and the City

1998 Joyce and Music

Williamstown 
1997 The Scandal of Ulysses Legal

Precinct and City

1996 Readings from Ulysses Acland

Street, St. Kilda and

Brunswick

St.

1995 Peripatetic Readings Collins

Street precinct and City

$1994 \quad$ Peripatetic Readings City and

Melbourne General

Cemetery

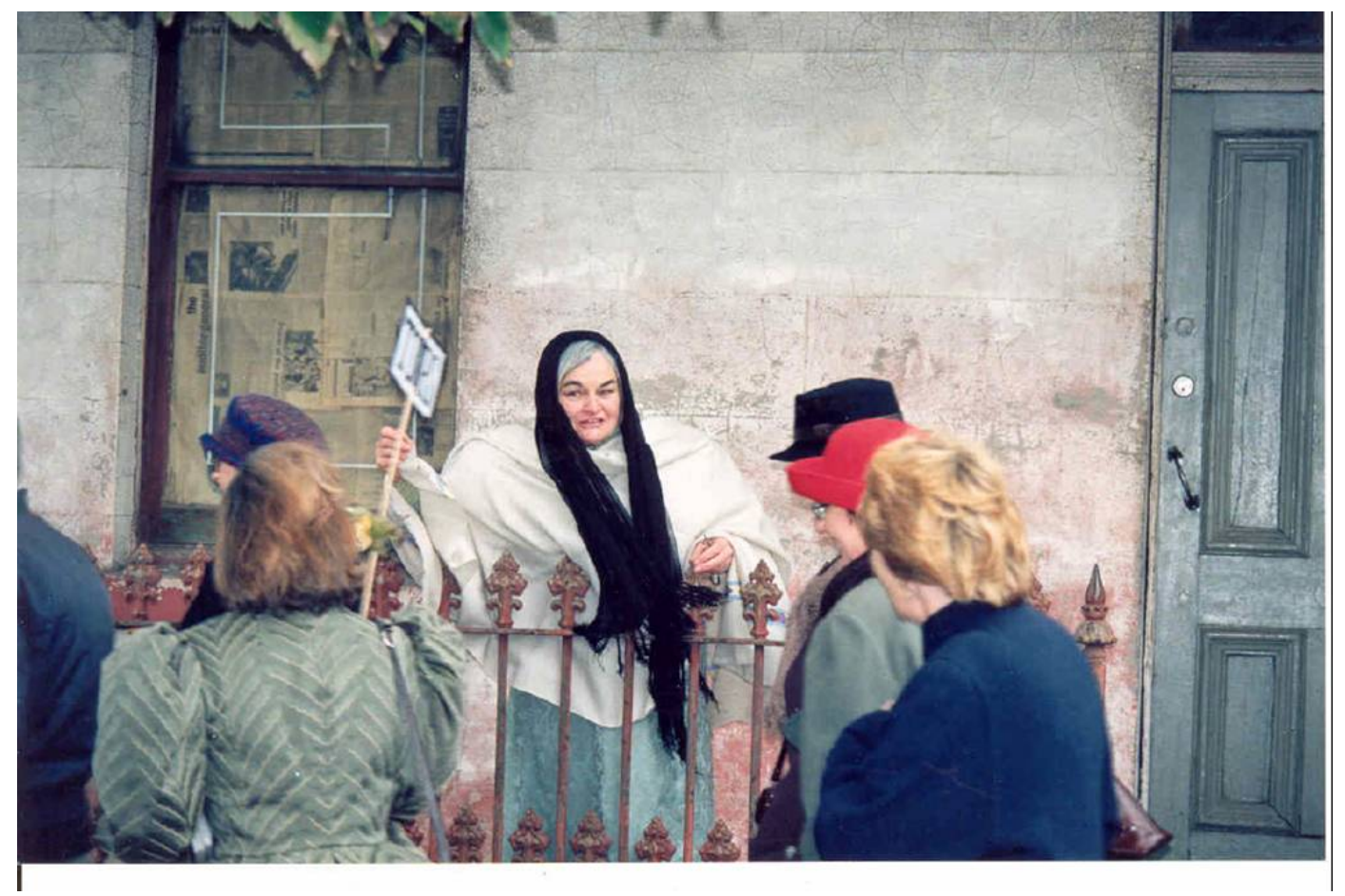

Gummy Granny, the Milkwoman, played by René Huish, advertises her wares to passersby in a laneway in North Melbourne.

Melbourne Bloomsdays have a predictable shape: they are peripatetic and consist of multiple events (as many as 16 in a day), climaxing in a more polished evening event, and there is always a seminar and sometimes a 'silly gig'. The evening gala occasion is always the most polished and rehearsed. In 2004-5 there is the luxury of a 3-day season but this is not normal. Because Bloomsday is a one-off, actors are normally not required to learn lines, and rehearsals are minimal. The Gala merits about 5 rehearsals including 3 all-day ones. This two-tier policy creates problems for Bloomsday in Melbourne, though, because theatricalisations can be uneven in quality because of different rehearsal regimes.

Seminars do not necessarily take an academic (or even literary) shape: historians able to compare Labor movements in Dublin and Melbourne in 1904 featured at the Trades Hall; for Joyce and music, musicians and scholars of musical performance compared the musical traditions of Dublin and Australia; and the First Eleven for Antipodean Joyce (2000) were 11 ordinary and not so ordinary non-literary readers of Joyce. In 1999, the year of Mythic Joyce, whereas street theatre events tracked Homeric allusions in a systematic way, the seminar looked at the suppressed and largely invisible substratum of Irish myth in the novel. They are also often adversarial: Writerly Joyce in 


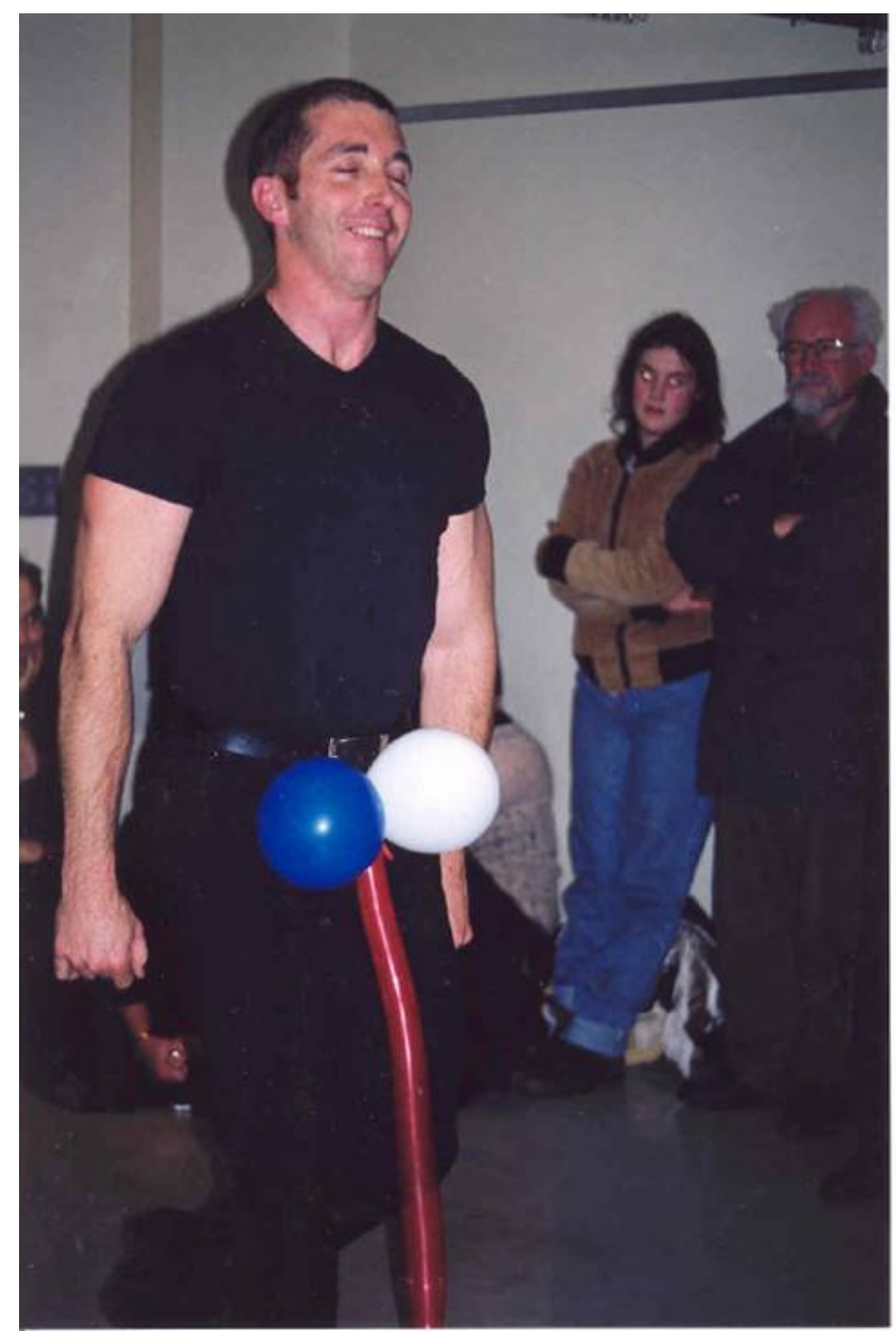

'Silly gigs' are a tradition of BM: in 1999, a champion Irish dancer choreographed a ballet for members of his school to accompany a dramatisation of the Swift parody from Oxen. It was as theatrical as anything Cuchulainn could perform in the way of a warp spasm (Kinsella pp.150-3), and it climaxed in the bull's castration by a vet: the red, white and blue testicular apparatus met its fate noisily but not as noisily as steel-heeled dancing shoes in a maternity ward. Also spectacular was the nude Saint Barbara who had a black mass intoned over her in the confined interior of Melbourne's oldest morgue at Williamstown. She came with an unanticipated bonus: a Celtic knot tattoed around her omphalos. Silly gigs had a function the committee realised only retrospectively. They enabled experimentation, and raised the expectations of patrons.

Originally the festival employed a trained actor/theatre director who corralled his acting friends for the purpose. His background in community and street theatre meant that surprises continually occurred, e.g. one of the first Bloomsdays, doing Gerty in the City Square, Simon McGuinness, in a completely unscripted manoeuvre, imaged Bloom's masturbation in the agitated rustle of greenery behind which he was standing. Similarly, at the end of Oxen in 2003, Jeff Keogh, who was playing an obnoxious and increasingly drunk medical student, turned to the audience, dropped his trousers, and wiped his fundament with his script. Writers would not dare to ask this from an actor, but it was an entirely appropriate improvisation. In important ways, the actors have shown us the way forward by resisting the pedagogical and encouraging the writers to take risks and to write more theatrically for them. Actors took a few years to learn how to read Joyce, but now are adept and do some of the dramaturgy for new actors. 
Although the festival has been fortunate in having passionate and risk-taking actors, the real key to the success of Bloomsday in Melbourne is the committee. In retrospect, one can chart a clear movement from unmediated readings with context to theatricalisations based on themes which allowed a more coherent and extended exploration of particular aspects of Joyce. As the committee gained confidence as writers and as readers of Joyce, they increasingly sought to use the book to argue with its maker, and they feel diminished if not able to exercise their writing skills in any particular year. However, this approach, which takes liberties with the text in moving well beyond readings, is controversial amongst the patrons. Sometimes characters interact with their maker and with contemporary characters, or contemporary advertising copy might be used for contrast with Bloom's dreams of his model house, or Stephen's meditation on Shakespeare might transmogrify into a debate between Shakespeare and Joyce. It is clear from the study I conducted that Irish-born patrons want their Joyce untampered with; Australians and Irish-Australians enjoy the less museum-like approach of debate, cultural comparison and critical engagement. An Irish-born patron wrote:

I cannot see how making Joyce 'Australian' or any other nationality, works to extend Joyce. Its very centre is Ireland, the works are Irish. These are the core areas to understand in order to be able to appreciate/understand/respect what Joyce is about. There is some danger in universalizing Joyce as if a panacea for contemporary issues.

The Irish-born patrons, who are small in number among those surveyed and in the body of patrons, express an understandable degree of ownership of the texts and are also more likely to be critical of the use of assumed accents and scripts that deviate from the text. Non-Irish-born patrons, of whatever lineage, tend to be more tolerant of creative engagements/disputes and interrogations of Joyce, and indeed to relish them.

Writing for Bloomsday is frequently a draw-card for writers to serve on the Bloomsday committee, and recycling old scripts has been anathema since 1995, being regarded by script devisors as a lost opportunity. In this respect, Bloomsday in Melbourne's practice is implicitly critical of both Sydney and Dublin Bloomsdays. In Dublin, unmediated and usually very brief readings, recycled annually in the same (authorized) locations, have become normative since 1996. European copyright considerations prevent them from deviating from the text and make mandatory scripts devised during the 'window of opportunity' between the lapse of the British copyright laws in 1991 and the imposition of the European copyright laws in 1996. In Sydney, for many years, celebrities were used to perform readings, often not especially skillfully, according to patrons who have attended them. The Melbourne committee began with contextualized readings in Edwardian quarters of the city, but the committee quickly tired of simply doing readings and found ways to both locate Joyce in relation to events in Australia and to indigenize it. For example, in Antipodean Joyce in 2000 with its commissioned a capella oratorio by Rod Baker based on the main character in the Wake, HCE, in turn based on HCE Childers, one of the founders of Melbourne University and the first Victorian Attorney General which was played by Ches Baragwanath (the Victorian State Attorney-General sacked by Jeff Kennett in 1999). Her Song be Sung, the original play taken to Dublin in 2004, dared to critique Joyce, which startled Dubliners who are used to more reverential treatments from Joyce aficionados. Another unique feature is the participation of patrons in minor roles, which has been an excellent device for building audiences and loyalty among the patron group, though it sometimes takes risks in relation to the quality and audibility of acting, especially when it occurs on the streets.

To return to Brannon's concerns: is this Joyce festival mediated by gurus, a top-down pedagogical enterprise? Initially it was. As the only academic in the group, I was the only one who had read the novel and had any interpretive competence. That quickly changed within the committee, and with it came a change in approach. The actors resisted the teacherly contextualisations (designed to draw attention to what was meaningful in the theatrical part of the event), and urged reform. Organisers had to learn to trust actors' communicative prowess - and to allow meaning to be carried theatrically, by voice, gesture, staging. However, there are risks in this. In 2002, a debate between Joyce and Shakespeare about who was superior was misunderstood by some patrons 
who did not know Scylla and Charybdis, Ch.9 of Ulysses, well enough to know that most of the debate came from Joyce's own fiction, though there was considerable tweaking to construct an argument and to accommodate the theme of putting Joyce into an enterprise bargaining hearing and interrogating his attitudes to work and workers. Similarly in Dublin, the play, Her Song Be Sung, created modern characters closely based on Joycean ones. If the audience is unfamiliar with Joyce, the point is going to be missed, even with explanatory program notes to buttress the production. Hopefully, the dramatic piece stands on its own terms, but the purpose of the enterprise for the committee is the intention to honour and debate with Joyce, and they do not want audiences to lose sight of that. It is often extremely difficult to construct a narrative thread out of a novel which is so minimal in its plotting as Ulysses is. There is little narrative, and Joyce resists narrative closure. In 2003, the committee dramatised the least theatrical chapter of the novel, Oxen of the Sun, as part of a thematic focus on Writerly Joyce. The State Library of Victoria's newly refurbished and very grand domed reading room functioned as Mina Purefoy's vastly pregnant belly and moreover gave an occasion for a trumpet voluntary and a sperm procession (grey helium balloons on sticks and threads), and a few spectacularly broken condom-balloons from which spermatozoa escaped into the dome. As well, the library constituted a literary context for Joyce's parodies of period styles. The fact that the chapter becomes increasingly inchoate in its final section (in line with Joyce's belief that English was in serious decline in the last quarter of the nineteenth century) became a problem for the scriptwriters. How were they to end this full-length theatre piece on a high? The solution was to somewhat restructure the ending by focussing on Bloom on creation.

Finally, I will briefly canvass the more practical and financial aspects of the operation of this festival. Arts administrators who have observed the success of the enterprise have advised the group to go commercial, to buy in their kind of expertise. While this is tempting, the management group is not convinced it is wise or necessary. Although the festival pays its way financially, remunerating (mainly fringe) professional actors, musicians and theatrical personnel, its financial base is admittedly shaky. Its cultural capital and organizational workforce is provided voluntarily by committee members. Funds to meet pre-production costs (mainly venue and lighting hire) for each Bloomsday are generated annually via small fundraisers, usually theatrical events or concerts held in patrons' or committee members' homes. Although Deakin University has been unfailingly generous and some useful sponsorship in kind has been forthcoming (Melbourne City Council, John Allison Monkhouse Funeral Directors) on an event-by-event basis, and the group has won grants (from the Department of Foreign Affairs and Trade and the Bank of Ireland Asset Management) to take the play to Dublin for the Bloomsday 100 festival in 2004, ongoing sponsorship has proven difficult. In the opinion of the committee, and at this stage in its development, the committee reluctantly deems such grantsmanship is not worth the time and effort expended, and concludes that time is better invested in the creative and teaching/learning departments than in fund-raising. What more secure money might buy is an arts administrator who can spend time raising such grants, buying in practical implementers and engaging in the multifarious tasks of running such an event: arranging rehearsals, publicity, negotiating in grainy detail with venues, food-providers, councils (who have astonishing rules about lavatories, cleaning up after horses from the hearse, under what conditions one may use a road or laneway rather than a footpath), and drawing up contracts with actors and crew. However, this is risky as the learning curve for an arts administrator is steep, and hands-on attention to detail is crucial to the success of the operation. So, the committee has chosen a different path: to curb ambition (and a fecundity of ideas for theatricalisations) with a view to keeping the festival manageable by a small number of personnel. Focus on Joyce, and the intellectual and communicative aspects of celebrating and interrogating him, have been the surer road to success.

This is a literary festival which is small in scale and runs on a shoestring. The evidence provided by patrons suggests that it occurs despite (and maybe because patrons seek to disprove?) the literary establishment's insistence that Joyce is too daunting for a general reader. The festival operates at the intersection of desire and need, stimulating re-

engagement not just with Joyce, but with other writers. The underconfident reader who 
has been attempting to read Joyce for 33 years without a great deal of a sense of achievement yet, commented:

without the annual phenomenon of Bloomsday, Joyce would have become merely the preserve of a few literary critics and some philologists.

He further noted that he wished similar festivals existed for other writers. He was not alone in expressing this view: patrons frequently pointed out in free comments that Joyce teaches them to read and reignites interest in other writers. What this may mean is that they are a readerly community. The debates that Bloomsday in Melbourne generates indicate that the festival charts a healthy course between celebration and critique of Joyce. It is the site of much feisty literary questioning of Joyce not only internally within the scripts, but also among the patrons (eg., '[James Joyce] has become such a cultural icon that nobody has the guts to say that great slabs of Ulysses are tedious, trivial or totally opaque'). The matter of Ireland is unavoidable with Joyce, and although not singularly pursued by the organisers, the Irish and Irish-Australian patrons, who constitute slightly less than half of the questionnaired, publicly and privately use Joyce to work through a fluid range of Irish or Irish-Australian identity issues. Interestingly the Australian-born, or those of other than Irish descent, who form more than half of the sample, have no basis for identity with Ireland or Irish-Australia, were convinced that Irish or Irish-identified patrons constitute the bulk of attendees, which is far from the case. The festival creates a measure of contention especially among those whose engagement with Ireland and Irish literature is of a romantic kind, but equally that reveals a kind of feisty ownership of Joyce by participants who have often come to him late in life. By its very existence and patronage, it problematises the notion that Joyce is the exclusive preserve of a literary élite. It also raises questions about why literary academe promulgates and persists with its own self-serving myths, and suggests new imperatives for bridging a gulf that exists between academe and real readers.

Further, and by way of challenge, it is a form of engagement with writing that could be readily adapted for many literary works. Had I, for instance, been in Australia in 2003, I would have been tempted to organize a bus-trip replete with a small team of actors through 'God's own Riverina' starting in Deniliquin and ending in Shepparton to celebrate the centenary of Furphy's Such is Life: the text would respond to writerly massaging because of its inherent theatricality and comedy, and immersion in Furphy's landscape and fiction, the better to experience its singularity and the visceral and spiritual ways in which he writes about it. Tim Winton's love-affair with sand and surf invites similar treatment. The possibilities are endless, and such celebrations do no harm to copyright earnings, sales, visibility of texts, and as well exercise writers' skills, and familiarity with those who've paved the way and exert the influences.

\section{Notes}

1) For a compilation of several of these see $<\mathrm{http}$ :// listsofbests.com/lists/1/> (accessed 17 Nov. 04). Return to text

2) In a forthcoming article in James Joyce Quarterly, I argue, among other things, that Joyce arrives on patrons' readerly horizon heavily freighted with canonical blessings, which are rarely problematised by them, and that its scarcity value and reputation for impenetrability and licentiousness increase its prestige. Return to text

3) An independent reader of Ulysses, self-proclaimed 'budding enthusiast' Kate Molloy of Westmeath was moved to be critical of the Irish Independent journalist, Ian O'Doherty's 'swipe at James Joyce': '... at first I too had reservations about the elder Joyceans. The whole thing did seem cliquish and elitist but I soon realised the only thing Joyceans are guilty of is obsessions - an obsession with Joyce, an obsession with discussing, reliving and giving up their lives in the pursuit of Joyce... These people were intelligent fans, not elitists... My point is that Joyceans let me into their world as a 20 -year-old with no background in academia, and I was not the only young person in attendance [at a summer school run by University College Dublin]' (Kate Molloy, 'Ian, Joyceans Aren't That Bad,' Irish Independent 9 June 2004 2004). Return to text 
4) For example, the Australian of 17 June 1996 featured a photo of a rival Bloomsday group in Melbourne sitting at a bar drinking Jameson (their sponsor), criticising the Bloomsday in Melbourne 'intellectuals' for 'destroying' Bloomsday as a holiday' with its 'ambitious program.' Instead, they argued, it should be kept 'simple, with a few readings over a glass of whiskey at the pub.' Return to text

5) Research for this paper is based on a detailed 10-page questionnaire distributed (largely by mail) to people on the Bloomsday in Melbourne mailing lists (some 250 of them, of whom 71 responded) and to 36 actors (of whom 11 responded), and follow-up focus groups and one-on-one interviews with 10 Irish or Irish-Australian volunteers. Return to text

6) The key issue was whether or not professional actors should be paid. Return to text

\section{References}

Brannon, Julie Sloan. Who Reads Ulysses? : The Rhetoric of the Joyce Wars and the Common Reader. Studies in Major Literary Authors ; V. 19. New York: Routledge, 2003. Return to text

Devlin-Glass, Frances. "'The Weight of Social Opinion on [His] Side"?: Ulysses, Censorship, Modernism and Canonisation, Australian-Style.' Irelands in the Asia-Pacific. Ed. Peter and Julie-Ann Robson Kuch. Gerrards Cross (UK),: Colin Smythe Ltd, 2003. 353-63. Return to text

Ellmann, Richard. James Joyce. New York: Oxford University Press, 1959. Return to text

Jones, Thomas. 'Short Cuts.' London Review of Books 23.24 (2001). Return to text

Joyce, James, et al. Ulysses. A critical and synoptic edition. New York: Garland Pub., 1984. Return to text

Kinsella, Thomas. The Táin. London, New York,: Oxford U.P., 1970. Return to text

McCabe, Colin. James Joyce and the Revolution of the Word. London and Basingstoke: Macmillan, 1978. Return to text

Molloy, Kate. "Ian, Joyceans Aren't That Bad." Letter to editor. Irish Independent 9 June 2004 2004: 29. Return to text

Read, Forrest, ed. Pound/Joyce: The Letters of Ezra Pound to James Joyce, with Pound's Critical Essays and Articles About Joyce. New York: New Directions., 1967. Return to text

Rose, Danis, ed. James Joyce/Ulysses. Dublin: Lilliput Press, 1996. Return to text

\section{Extra pics:}


Frances Devlin-Glass TEXT Special Issue No 4

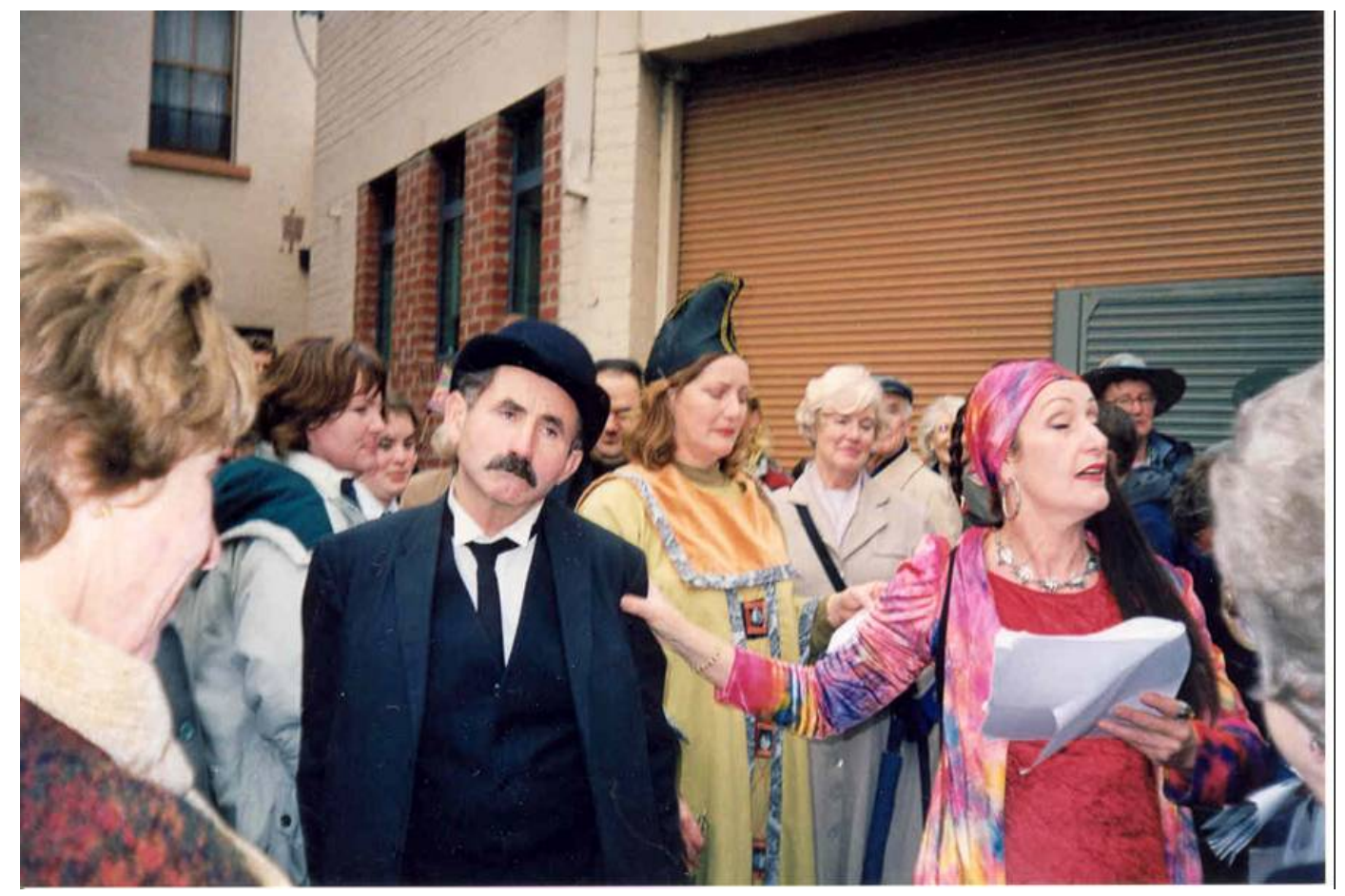

Bloom (Jim Howard) in pensive mode in an inner-city laneway.

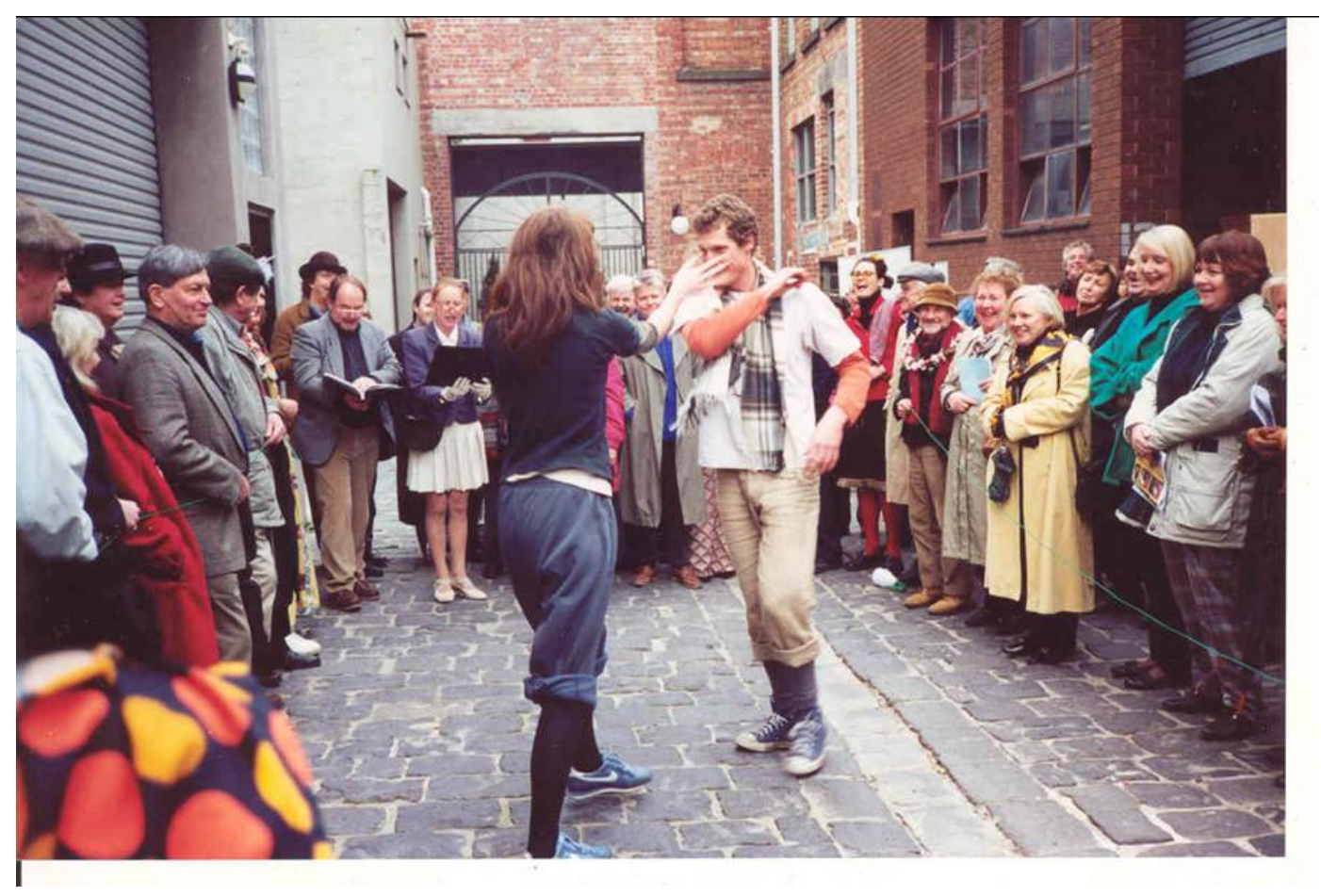

The Dublin Lamb takes on the Portobello bruiser, in the re-enactment of a politically un-innocent boxing match. 


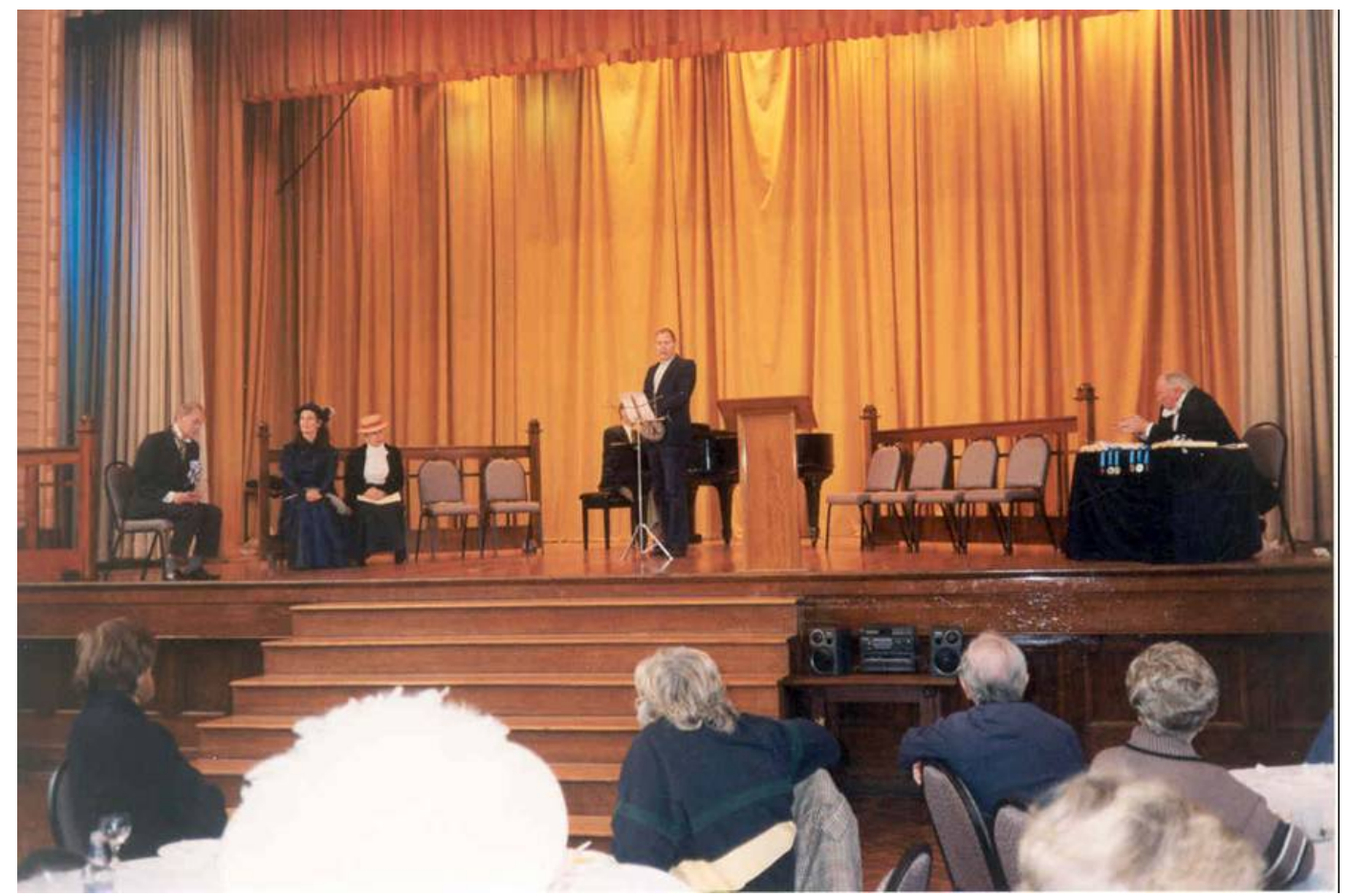

A re-enactment at the Williamstown Town Hall in 1998 of the Feis Ceoil (Music Eisteddfod) in which Joyce competted in Dublin in May 1904, provided an opportunity to explore the parlour music of Dublin circa 1900.

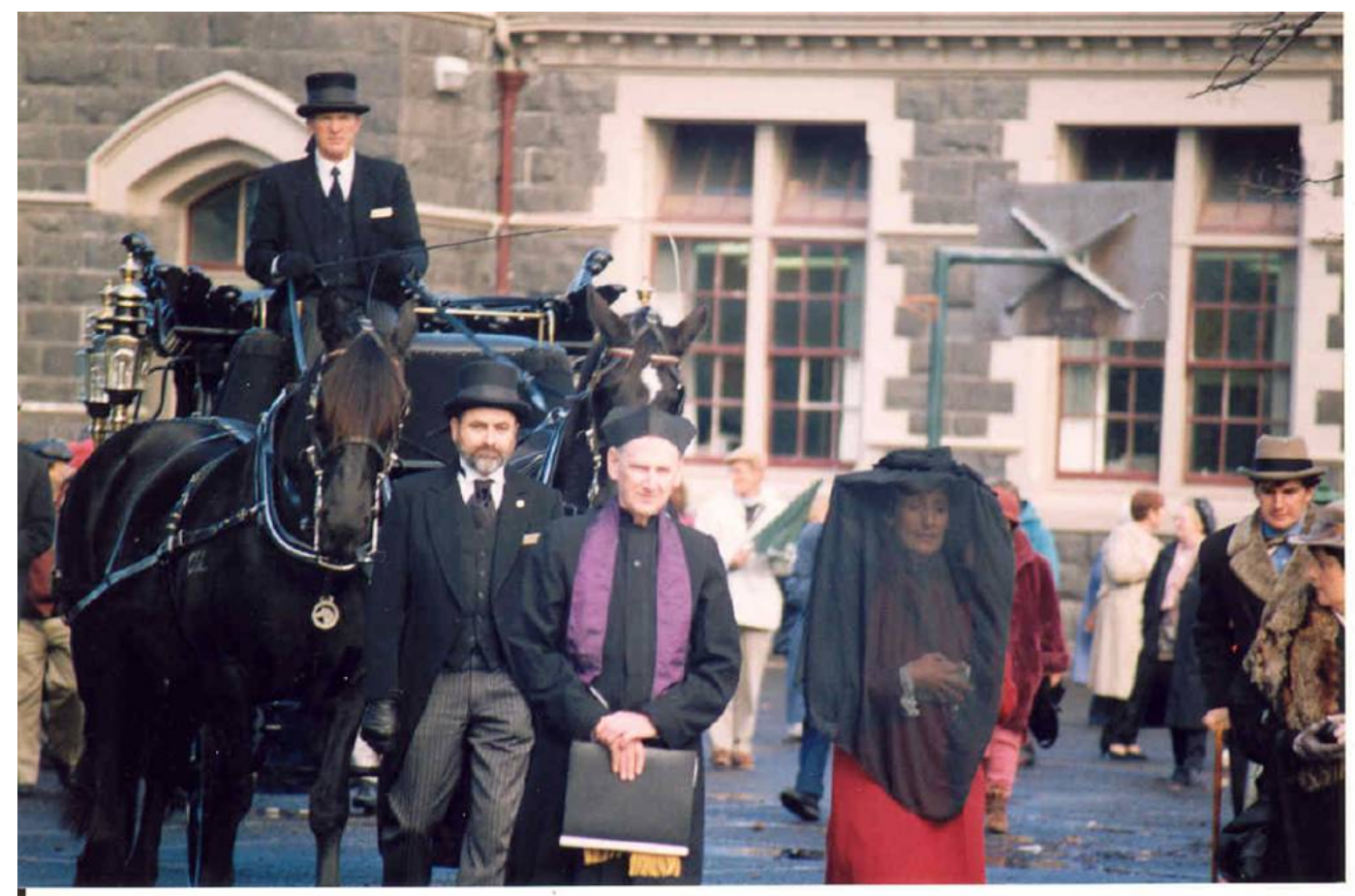

Paddy Dignam's funeral procession. (Williamstown 1998). 


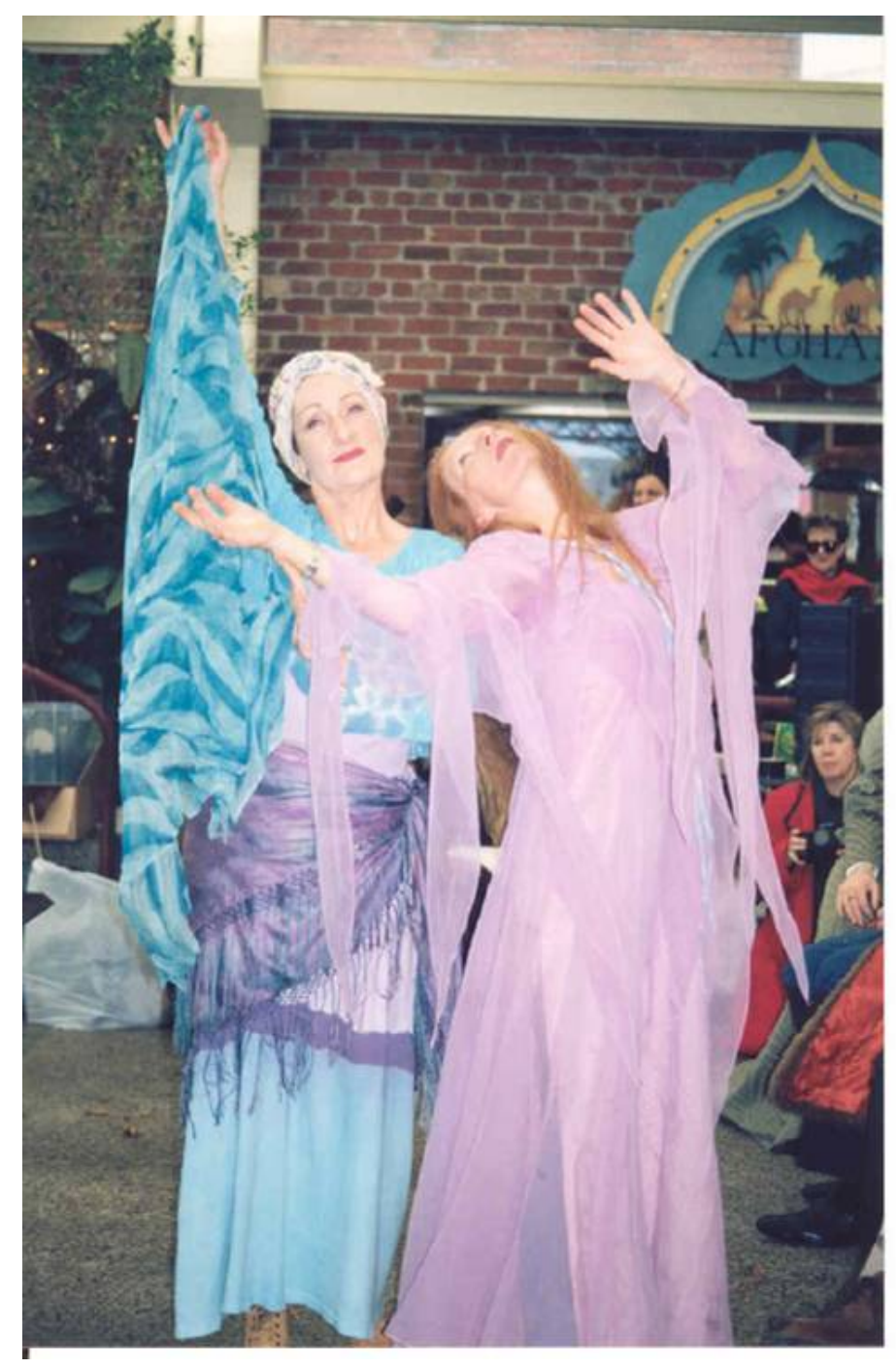

The Poulaphouca and Anna Livia river nymphs dance under the sign of the fish and above a subterranean river at the Victoria Market, 2000.

Associate Professor Frances Devlin-Glass teaches Literary Studies at Deakin (Melbourne Campus). She has been director of Bloomsday in Melbourne since 1994. The group was recently commissioned by the James Joyce Centre (Dublin) to perform an original play, Her Song be Sung, for the centenary of the date on which the novel was set, in 2004 at the ReJoyce Dublin 2004 Festival in Dublin.

\author{
TEXT Special Issue \\ No 4 October 2005 \\ http://www.griffith.edu.au/school/art/text/ \\ Editors: Wenche Ommundsen and Maria Takolander \\ General Editors: Nigel Krauth \& Jen Webb \\ Text@griffith.edu.au
}

